\title{
RELACIONES URBANAS DEL CABILDO CATEDRAL EN LA CORDOBA DEL QUINIENTOS
}

\author{
por AlbertoVillar Movellan \\ María Teresa Dabrio Gonzalez
}

\begin{abstract}
La trama urbana es utilizada por el Sacro Colegio cordobés con diversas motivaciones, dentro de una proyección social que requiere la continua presencia de sus miembros fuera de los muros de la Catedral. Ello provoca la explosión de conflictos con los intereses del Ayuntamiento, empeñado en una labor urbanística de ensanches que facilitaran la circulación comercial. En estas relaciones urbanas intervienen afamados arquitectos y canteros como los Hernán Ruiz, Martín Ruiz, Hernando de Zavala y otros. A través de las actas capitulares es posible acercarse a los intereses económicos, al afán de representatividad y poder y al control de los subordinados que marcan el pulso vital del Cabildo Catedral a lo largo de la centuria del Quinientos.
\end{abstract}

The city itself was, for various reasons, of great importance to the Sacred College of Córdoba, given its social role which called for the continuous presence of its members outside the Cathedral walls. This gave rise to conflicts with the interests of the Town Council, which was set on a project of road-widening to ease commercial traffic. In this context of urban development appear a number of famous architects and stone masons, like the Hemán Ruiz family, Martín Ruiz, Hemando de Zavala and others. Documents of the chapter give some idea of the economic interests, the desire for representation and power, and the control over subordinates which mark the life of the Cathedral Chapter throughout the 16 th century.

En 1990 aportó Jorge Bermales Ballesteros una magistral visión de conjunto del "Urbanismo del Quinientos" dentro del tomo Arte del Renacimiento (Arquitectura y Urbanismo) perteneciente a la Historia del Arte en Andalucía publicada en Sevilla. Allí queda de manifiesto la pujanza de las ciudades andaluzas del Renacimiento entre las que Córdoba descolló especialmente gracias al momentáneo desarrollo económico que le proporcionaron las transacciones comerciales entre las dos zonas geográficas fundamentales de su reino: la Sierra y la Campi- 
ña. Ese enriquecimiento pasajero, nunca bien aprovechado, produjo en la ciudad una actividad urbanística sin precedentes ni consecuentes en la época moderna. La ciudad, sus ambientes y sus transformaciones se viven con plenitud en el marco de la cultura del Humanismo. La construcción de la ciudad todo lo inunda y las fuentes documentales permiten asomarse de manera simultánea a los distintos aspectos de esta realidad urbanística.

En esta ocasión hemos optado por asomarnos a la ventana abierta de las Actas del Cabildo de la Catedral de Córdoba, institución de reconocido protagonismo en el desarrollo urbano de la ciudad. La trama urbana es utilizada por el Sacro Colegio cordobés con diversas motivaciones, dentro de una proyección social que requiere la continua presencia de sus miembros fuera de los muros de la catedral. En este sentido las calles son el marco de constantes procesiones capitulares para las que frecuentemente se dispone un ritual fuertemente escenográfico; las numerosas casas que posee la institución catedralicia facilitan la explosión de conflictos con los intereses del Ayuntamiento, empeñado en una labor urbanística de ensanches que facilitaran la circulación comercial, hecho tan característico en las ciudades mejor integradas en la cultura del Renacimiento.

Los intereses del Cabildo atañen a los mercados de Córdoba, mientras que las obras que emprende por su cuenta son a veces discutibles desde el punto de vista municipal. En fin, el Cabildo hace también ciudad mediante el control de obras de esas micropoblaciones que son los conventos dejados bajo su patronato, entre los cuales es sin duda el de la Encarnación uno de los más activos. En estas relaciones urbanas intervienen como técnicos afamados arquitectos y canteros como los Hernán Ruiz, Martín Ruiz, Hernando de Zavala y otros que a la luz de las actas capitulares quedan desposeídos del hálito creador con que normalmente solemos admirarlos los historiadores para bajar a la realidad cotidiana y prosaica de las mediciones, tasaciones e informes, siempre bajo la atenta vigilancia de una comisión de canónigos.

Así pues, a través de las actas capitulares es posible acercarse a los intereses económicos, a la defensa de los privilegios, al afán de representatividad y poder y al control de los subordinados que marcan el pulso vital del Cabildo Catedral a lo largo de la centuria del Quinientos. Ahora pretendemos tomárselo en tres aspectos diferentes: en sus relaciones con la Corona, con el Ayuntamiento y con las monjas de la Encarnación. 


\section{EL CABILDO Y LA CORONA}

\section{La crisis de la capilla Mayor}

Las relaciones del Cabildo con la Corona tuvieron uno de los momentos más difíciles en los días del obispo Alonso de Manrique, cuando se decidió en 1521 hacer la obra nueva de la Capilla Mayor y Coro. La Corona se vio envuelta entonces en la disputa que mantuvieron los Cabildos municipal y catedralicio acerca de si procedía o no llevar a cabo aquella ostentosa obra. Estaban demasiado recientes los problemas políticos derivados del conflicto de las Comunidades en los que Iglesia y Nobleza habían adoptado posturas diferentes. La Corona tuvo un difícil papel de arbitraje en el que dio la razón primero a la Iglesia y más tarde al Ayuntamiento, quedando finalmente a bien con unos y otros, sin que el progreso de la ingente obra emprendida por el obispo Manrique sufriera menoscabo alguno por estas diatribas.

Aunque se ha tratado de justificar la postura del Cabildo con una mínima referencia a que no estaba de acuerdo con la realización de la obra ${ }^{1}$, los cierto es que a medida que ésta avanza los capitulares se apresuran a pedir capillas para enterramiento cabe los muros de la nueva fábrica y, aún más, instan encarecidamente al obispo para que no suspenda los trabajos de construcción; así se desprende de varios documentos en los que se expresa la grave preocupación del Cabildo ante la posibilidad de que no se recuperaran los fondos destinados a la fábrica y desviados para ayudar a la Corona. En efecto, en enero de 1528 el emperador solicita a la Iglesia de Córdoba 200.000 maravedíes para colaboración a la guerra contra Francia ${ }^{2}$, y el obispo transmite la petición al Cabildo; éste escribió al prelado “...sobre razón que no permitiese su Señoría cesase la obra de esta iglesia por el prestado de los 200.000 que su Majestad quiso de esta fábrica prestado, las cuales letras su Señoría dio licencia".

Incluso el Cabildo dispone la venta de cruces, cálices y custodias para obtener dinero con tal de que siga la obra: "...envió poder su Señoría al obrero, el

1. Nieto destaca este aspecto basándose en una frase recogida en las Actas Capitulares de 1523, con motivo de buscar alojamiento para dos albañiles: "este día los señores deán y Cabildo dieron la casa de San Sebastián que solía ser hospital en que vivan dos maestros albañiles y carpinteros, que labren en la obra que se hace en esta iglesia, que no debiera hacerse". "Aportación documental a la obra de Hernán Ruiz l en la mezquita-catedral de Córdoba (1513-1547)". Homenaje a Dionisio Ortiz Juárez. Córdoba, 1991, págs. 223.

2. 1528, enero 17, Córdoba: Se llama a Cabildo para decidir sobre el préstamo de 200.000 maravedíes solicitado por el monarca. El 7 de febrero del mismo año se acuerda la concesión del préstamo solicitado. Archivo de la Catedral de Córdoba (A.C.C.). Actas Capitulares 1525-1533, t. 10 , $\sin$ foliar. 
canónigo Hernando Alonso de Riaza para poder obligar los bienes todos de la fábrica (a quien) le prestare algunas sumas de maravedíes para que no cesen los maestros de labrar y así mismo para vender y deshacer toda la plata que está en la sacristía, demasiada de la que es menester para el servicio del altar, de cálices, y cruces y custodias y para esto diputó el Cabildo con el Señor Provisor para ver la plata que se ha de vender al licenciado Diego Bello y Riaza y Martín Alonso Pichín en lugar del señor tesorero". Y por si aún no bastara con ello, se pide prestada una considerable cantidad de dinero que aportan los propios canónigos, empeñando los bienes de la fábrica; así prestan dinero el maestrescuela, el tesoréro, el chantre, el licenciado Diego Bello, Alonso Sánchez de Avila y otros ${ }^{3}$.

Queda pues fuera de toda duda que los capitulares catedralicios estaban absolutamente comprometidos en la nueva obra de la capilla mayor y coro, y se esforzaban en las gestiones tendentes al feliz término de la misma. Incluso parece lícito sospechar que el Cabildo se distanció de la Corona cuando ésta -en lo que creemos un alarde de habilidad diplomática- ${ }^{4}$ pareció privar de su favor a los promotores de la obra para dar la razón a los concejales del Cabildo municipal que habían protestado airadamente por la misma. En este sentido llama poderosamente la atención que ni siquiera se reseñe en las Actas Capitulares de 1526 la presencia del monarca en la ciudad, cuando el Cabildo eclesiástico se prodigaba normalmente en muestras de hospitalidad y en adhesiones a la Corona ${ }^{5}$.

Para 1528, como se ha visto, las aguas habían vuelto ya a su cauce y el Cabildo, aunque con reticencias, aporta dinero para las campañas reales contra Francia $^{6}$. A partir de ese momento se aprecia la creciente cordialidad en las relaciones entre el Cabildo y la Corona que se intensificarán con la llegada a la Sede de don Leopoldo de Austria, tío del Emperador, y más aún desde que se encarga de los asuntos de España el príncipe Felipe.

3. Los prestamistas y las cantidades aportadas fueron los siguientes: el maestrescuela, cincuenta ducados; el chantre, cincuenta mil maravedíes; el tesorero, treinta mil maravedíes; el licenciado Diego Bello, treinta mil maravedíes; el canónigo Alonso Sánchez de Avila, cincuenta ducados; Pedro de Angulo, cincuenta ducados; Mosén García, treinta ducados. A.C.C. Actas Capitulares 1525-1533, t. 10, sin foliar.

4. Villar Movellán, Alberto: "La Arquitectura del Quinientos". Córdoba y su Provincia, t. III. Sevilla, 1986, pág. 213.

5. Hemos revisado en las Actas Capitulares todos los acuerdos correspondientes a 1526 y no se hace ninguna alusión al rey ni a ninguna ceremonia protocolaria en relación con su estancia en la ciudad.

6. Ya en enero de 1527 se enviaron a Valladolid dos beneficiados a petición real. A.C.C. Actas Capitulares 1525-33, t. 10, sin foliar. 


\section{Procesiones para Felipe}

Las atenciones del Cabildo pueden considerarse hasta excesivas en las décadas centrales del siglo: ante cualquier noticia proveniente de la Corte se organizan con prontitud plegarias, rogativas o procesiones, generalmente con estación en el monasterio de la Trinidad o en el convento de San Pedro el Real. Así por ejemplo el 9 de junio de 1554 se hacen plegarias en las misas y procesión a la Trinidad para que el príncipe Felipe prepare convenientemente su viaje a Inglaterra, donde le esperaba el amoroso encuentro con su prima y futura esposa María Tudor. En septiembre del mismo año el Cabildo hace procesión para que el regio consorte arribe felizmente a Inglaterra. Así también a su regreso en 1559: en agosto, a la Trinidad para que haga bien la travesía, y en septiembre, a Santa Cruz para dar gracias por el feliz viaje ?

Igualmente festejadas eran las noticias de los partos reales, como en 1566, cuando se hizo procesión de gracia a San Francisco por el nacimiento de la Infanta Isabel Clara Eugenia, y de nuevo un año después cuando se hacen ruegos por el buen alumbramiento de la Reina ${ }^{8}$, y en octubre de aquel 67 al monasterio de la Trinidad para dar gracias por el buen parto en el que vio la luz la Infanta Catalina Micaela ${ }^{9}$.

Con no menor respeto se acogían las noticias luctuosas de la familia real; en mayo de 1539 se celebraron solemnes exequias por la emperatriz Isabel, de tal grandeza que quedaron en la memoria de la Iglesia de Córdoba, pues en 1545, a la muerte de la Princesa María de Portugal, primera esposa del príncipe Felipe, el Obispo don Leopoldo de Austria pide al Cabildo que haga honras fúnebres tan solemnes como las que se habían celebrado por el alma de la emperatriz Isabel ${ }^{10}$.

En octubre de 1558 la Princesa Juana de Austria, en su papel de regente por ausencia de Felipe II, comunica la muerte del emperador Carlos, y el Cabildo general acepta hacer honras y sacrificios por su alma, mandando, de común acuerdo con el Cabildo de la ciudad, que doblen las campanas en todas las iglesias de Córdoba, y el día 23 del mismo mes se ordenaron honras fúnebres en

7. 9 de junio de 1554: Plegarias y procesión a la Trinidad para pedir por el viaje del Príncipe a Inglaterra. A.C.C. Actas Capitulares 1549-1556, t. 14. Sin foliar. 12 de septiembre de 1554: Procesión del Cabildo a Santiago y a Santa Cruz para la buena arribada del príncipe a Inglaterra. A.C.C. Actas Capitulares 1549-1556, t. 14, sin foliar. Viaje de 1559: A.C.C. Actas Capitulares 1558-60, t. 16, sin foliar.

8. A.C.C. Miércoles, 19 de julio de 1566. Actas Capitulares 1565-1568, t. 19, fol. 73. Jueves 29 de agosto de 1566. Actas Capitulares 1565-1568, t. 19, fol. 84 v. 27 de septiembre de 1567. Actas Capitulares $1565-1568$, t. 19, fol. 90.

9. A.C.C. 14 de octubre de 1567. Actas Capitulares 1565-1568, t. 19, fol. 93 v.

10. A.C.C. 31 de julio de 1545. Actas Capitulares $1545-1549$, t. 13, fol. 8. 
todas las iglesias del obispado, para lo que se dispuso el correspondiente protocolo de atuendos y ceremonial ".

Diez años después, en el corto espacio de dos meses, el Cabildo hubo de celebrar también honras fúnebres por el desgraciado heredero, el príncipe Car$\operatorname{los}^{12}$, y por la querida reina Isabel de Valois, las primeras el 10 de agosto y las segundas el 24 de octubre ${ }^{13}$; para éstas se mandó "hacer el túmulo entre los dos coros", trasladándose las horas canónicas a la capilla del cabildo.

No faltaron procesiones y misas de acción de gracias por razones más apropiadas a los intereses de la Iglesia, como es el caso de las celebraciones a que da lugar la carta de la reina María Tudor en febrero de 1555, comunicando que Inglaterra había aceptado volver a la religión católica ${ }^{14}$; la procesión de 1563 a la iglesia de Santiago para celebrar las victorias de Orán y Mazalquivir, o la memorable al monasterio de la Victoria en acción de gracias por el triunfo de Don Juan de Austria frente a los turcos en $1571^{15}$.

El Cabildo colabora igualmente en cuantas actividades es requerido al servicio de la Corona. El 30 de octubre de 1573 el prelado Fray Bernardo de Fresneda se presentó ante el Cabildo a petición del Obispo de Jaén, quien había sido comisionado por el rey para ir a Granada y hacerse cargo del traslado de los cuerpos de la emperatriz Isabel y otros personajes reales al nuevo enterramiento de El Escorial. Para ello se requería el auxilio del cabildo cordobés, al que se le solicitaban algunos cantores y ornamentos varios, concretamente, un contrabajo, un tiple y el mejor terno de Requiem de los que hubiese en la Sacristía ${ }^{16}$.

\section{Protocolo del real recibimiento}

Hacía muy poco tiempo que el Cabildo catedralicio había tenido oportunidad de mostrar su afecto a Felipe II con motivo del establecimiento provisional de la

11. A.C.C. Actas Capitulares $1558-1560$, t. 16, sin foliar.

12. A.C.C. Actas Capitulares $1565-1568$, t. 19, fol. 166. La enfermedad de Carlos fue seguida puntualmente por los capitulares. En mayo de 1562 se ordenaron misas por su mejoría y procesiones a la iglesia del Salvador, las cuales terminaron con la solemne misa de la salud, el 10 de mayo. $\mathrm{Al}$ tenerse noticia del alivio, a primeros de junio, se organizó procesión a la Trinidad con Te Deum en acción de gracias. A.C.C. Actas Capitulares. 1560-62, t. 17, fol. 174.

13. A.C.C. Actas Capitulares $1565-1568$, t. 19 , fol. 190 v.

14. 25 de febrero de 1555: Se acuerda hacer procesiones y misas en acción de gracias por la decisión de Inglaterra de volver al seno del catolicismo, según lo comunicaba la carta de la Soberana. A.C.C. Actas Capitulares 1549-1555, t. 14, sin foliar.

15. A.C.C. Actas Capitulares $1568-1572$, t. 20, fol. 233. La acción de gracias por Orán y Mazalquivir tuvo lugar el 16 de junio y los asistentes fueron premiados con dos reales. A.C.C. Actas Capitulares 1562-1564, t. 18, fol. 109.

16. A.C.C. Actas Capitulares 1572-1573, t. 21, fol. 277 y v. 
Corte en Córdoba en 1570, probablemente la ocasión más fastuosa de la historia de la ciudad en la época moderna. Teniendo en cuenta que el rey iba a establecer sus reales en el Palacio Episcopal y que el séquito se instalaría en el Hospital de San Sebastián, los canónigos asumieron el papel de huéspedes de la ilustre comitiva. Así pues el Cabildo recibió el 27 de diciembre de 1569 la visita de los aposentadores reales don Fernando de Frías, don Francisco de San Vicente, y don Juan Díaz de la Peña ${ }^{17}$. Tres días más tarde, el obispo don Cristóbal de Rojas pide al Cabildo que desaloje el hospital de San Sebastián y que los pobres enfermos se trasladen al Hospital de Antón Cabrera, también patronato del Cabildo ${ }^{18}$. Como última providencia, el martes 17 de enero de 1570 se ordena que el Cabildo en pleno, con mantos y becas, acuda a recibir a su Majestad - so pena de perder los oficios del mes- en el orden y lugar que le fuere asignado por los encargados del protocolo ${ }^{19}$.

El protocolo del Cabildo para el viaje real, que tuvo lugar el 20 de febrero de 1570 , es uno de los documentos mejor cuidados de cuantos se redactaron para este tipo de acontecimientos en el Renacimiento cordobés ${ }^{20}$. Sin duda ha de entreverse en ello el interés del obispo don Cristóbal de Rojas porque la visita fuera un éxito rotundo, habida cuenta de la ferviente admiración del prelado por la casa real. Don Cristóbal de Rojas había sido capellán imperial y conciliar de Trento, y a raíz de la visita regia sería promovido a la sede arzobispal de Sevi$\mathrm{lla}^{21}$. Incluso antes de la llegada de los aposentadores, el obispo ya había dado los primeros pasos para asegurar la brillantez de los actos, haciendo revisar todo lo concerniente a la música sacra que fue una de sus principales preocupaciones ${ }^{22}$.

Tal como queda reflejado en el documento, el Cabildo en pleno con el pertiguero a la cabeza, a lomos de cabalgaduras, debía partir en comitiva desde el Palacio Episcopal hasta el lugar de encuentro con el séquito real; en aquel sitio pasarían a besar las manos del Rey por orden de antigüedad hasta que su Majestad se cansara, estando uno de ellos junto al monarca para presentarle a los cabildantes. Luego el Cabildo debía volverse para revestirse y recibir al rey en la Puerta del Perdón en un altar ricamente ornamentado y presidido por una reliquia

17. A.C.C. Actas Capitulares 1568-1572. t. 20, fol. 94 y v.

18. A.C.C. Actas Capitulares 1568-1572, t. 20, fol. 95.

19. A.C.C. Actas Capitulares 1568-1572, t. 20, fol. 98 v.

20. Protocolo para el recibimiento del rey. Apéndice documental n. 93 . 469-470.

21. GOMEZ BRAvO, J.: Catálogo de los obispos de Córdoba, t. II. Córdoba, 1778, pág.

22. Con motivo de la visita real, el Cabildo manda revisar los estatutos y ver cuáles eran las necesidades prioritarias al respecto. A.C.C. Actas capitulares 1568-72, t. 20, fol. 92 . Para la relación del prelado con la música véase DABRIO GONZALEZ, M.T.: "La capilla musical de D. Cristóbal de Rojas en la Catedral de Córdoba". Laboratorio, n. 9. 
en vaso de vidrio, que acaso podría identificarse con el Relicario de San Bartolomé del tesoro catedralicio, que efectivamente tiene copa de cristal de roca sustentada por pie de metal adornado con nudo poligonal, fechable en el siglo XV ${ }^{23}$.

La ceremonia sería presidida por el preste con diácono y subdiácono estando presente el sochantre con capa de seda y vara para llevar el compás. Una vez que el monarca llegase a la Puerta del Perdón y se arrodillase en el estrado cubierto con dosel de brocado levantado con tal fin, el cardenal, o en su defecto el obispo, le echarían el agua bendita ${ }^{24}$. Después, el obispo con sus dos asistentes presentarían al rey la reliquia para que este la besara, iniciándose entonces por el sochantre el canto de un responso, y así, cantando, debía dirigirse todo el cortejo hasta el altar mayor en cuyo lado de la epístola habría otro estrado con dosel, banco y almohada para el monarca; tras las oraciones pertinentes, el obispo impartiría la bendición solemne. En el protocolo se recoge finalmente que a esta ceremonia asistiesen el mayor número posible de cabildantes revestidos con capas de brocado y se recuerda de nuevo que a los que no cumpliesen lo mandado se les penalizaría económicamente.

Durante los meses que la corte estuvo establecida en la ciudad tanto el prelado como el Cabildo se esmerarán en las ceremonias del culto y muy especialmente en las intervenciones musicales, ya que con toda probabilidad el monarca asistiría con frecuencia a aquellas. Así, en marzo de 1570 el Cabildo catedralicio acuerda gratificar a "los cantores españoles de la Capilla de su Majestad el servicio que han hecho en las completas" ${ }^{25}$.

\section{EL CABILDO Y LA CIUDAD}

\section{El Rastro de la Corredera y las Carnicerías del Salvador}

La riqueza que acumuló la ciudad de Córdoba en las décadas centrales del siglo XVI podrían hacer pensar que propiciara fructíferas relaciones entre los dos Cabildos, el secular y el eclesiástico. Sin embargo el pulso de los intereses tomado mediante el análisis de las Actas Capitulares de la Catedral nos transmite

23. LAGUNA PAUL, T.: "El segundo arte cristiano". En Córdoba y su provincia. t. III, Sevilla, 1986, pág. 201.

24. Según recoge Ramírez de las Casas Deza, el cardenal que acompañaba al monarca fue don Diego de Espinosa, presidente del Consejo Real e Inquisidor Mayor, el cual residió primero en las casas de don Diego Fernández de Córdoba y luego pasó al Hospital de San Sebastián para estar más cerca de la residencia real. Cfr. Anales de la ciudad de Córdoba desde el siglo XIII hasta 1850. 1570. Manuscrito en la Biblioteca Municipal de Córdoba.

25. A.C.C. Actas Capitulares 1568-1572, t. 20, fol. 106 v. y 107. 
una imagen absolutamente decepcionante. De ellas podemos inferir que la Ciudad anda preocupada en labores de ensanche y adecentamiento promovido por algunos de sus más ilustres corregidores como don Francisco Zapata de Cisneros, mientras que la Catedral anda obcecada en mantener las propiedades afectadas por los ensanches o sacar de sus derribos el mayor partido posible, lo que si es en principio comprensible, no justifica los largos pleitos y situaciones extremas a que se vieron obligadas las autoridades en virtud de las constantes trabas planteadas por el Cabildo catedralicio.

En relación con la visita de Felipe II se ha situado el origen de la famosa Puerta del Puente, la obra civil más vistosa de Hernán Ruiz III y una de las realizaciones urbanísticas más emblemáticas de la Córdoba del Quinientos. De esta fábrica ya se había ocupado Rafael Romero Barros a fines del siglo XIX y en fechas más recientes ha sido detalladamente estudiada por Antonio de la Banda ${ }^{26}$. Por ellos sabemos que la Ciudad decidió su arreglo a causa de su vetustez a raíz de la estancia del monarca. Se acordó su recrecido y dignificación en 1572 encargándose finalmente de la obra el mencionado arquitecto y quedando a la postre inconclusa, tras una serie de vicisitudes, en 1576. Una nota en las Actas del Capítulo eclesiástico, sin embargo, nos demuestra que el Concejo de la ciudad ya había emprendido obras en la Puerta del Puente en 1563 y probablemente no se trate de obras menores, a juzgar por las palabras registradas en actas y la preocupación del Cabildo porque no sufrieran daños con las obras sus molinos de la Añora: "Este día sus mercedes trataron de una puerta que hace la ciudad a la Puerta de la Puente a la parte que desciende a las aceñas de la Añora de que se presume perjuicio en las dichas aceñas" ${ }^{27}$. Si hubiese existido un proyecto anterior, como parece colegirse, ello explicaría aún mejor la estrecha relación que el diseño de Hernán Ruiz III tiene con otras obras de su padre, pues de existir trazas en 1563 se habrían debido con seguridad a Ruiz el Joven. Sin embargo, de la documentación conocida se deduce que en todo caso la obra no quedó a gusto, pues en 1572 se estimó que era necesario recrecerla y embellecerla.

Por curioso que pueda parecer son muy escasos aunque tediosos los asuntos urbanos que preocupan a los cabildantes. Desde 1528 se plantean en firme dos

26. ROMERO BARROS, R.: "Estudios sobre arquitectura española en el siglo XVI". Bol. Acad. de San Fernando. n. 74. 1888, pág. 117-124. Cit. por BANDA Y VARGAS, A.: El arquitecto andaluz Hernán Ruiz II. Sevilla, 1974, pág. 228 y ss.

27. Miércoles, 16 de junio de 1563: Que vayan a ver la puerta que se hace en la puente (al margen). "Este día sus mercedes trataron de una puerta que hace la ciudad a la Puerta de la Puente a la parte que desciende a las aceñas del Añora de que se presume perjuicio en las dichas aceñas. El Cabildo mandó que se renuncie (?) de nueva obra y que lo vaya a ver el canónigo Riaza y el señor Rodrigo Barrionuevo". A.C.C. Actas Capitulares 1562-1564, t. 18, fol. 108 v. 
actuaciones por parte del Ayuntamiento, que van a agriar las relaciones urbanísticas de ambos cabildos a lo largo del siglo: el Rastro de la Corredera y las Carnicerías del Salvador. El Ayuntamiento pretendía trasladar el Rastro de la Corredera con idea de ensanchar aquel espacio para obtener la vistosa plaza de ese nombre, que sólo se conseguiría en su estado definitivo siglo y medio más tarde. El ensanche afectaba a unas casas del Cabildo ${ }^{28}$, ocupadas por las tiendas del Rastro, actividad que el Ayuntamiento quería llevar a la Puerta de Gallegos o a otro lugar que se determinara. La Ciudad pretendía que aquellas casas se derribaran en su mayor parte, salvo un trozo que se reformaría como tienda para el peso de la fruta y otras mercaderías.

El otro punto de interés municipal estaba en la Plaza del Salvador, donde el Cabildo tenía otras casas ocupadas por las Carnicerías Viejas, en cuyo lugar la Ciudad quería construir una oficina para un contraste ${ }^{29}$.

El Cabildo Catedral debatió la propuesta municipal y resolvió aceptar el traslado del Rastro de la Corredera a la Puerta de Gallegos con la condición de no perder los privilegios económicos de que disfrutaba en la Corredera. La otra condición era que el solar edificable resultante se repartiese por partes iguales entre la Ciudad y la Iglesia para que cada cual construyera por su cuenta, siempre que la mitad que correspondiese al Cabildo Catedral fuera la que daba hacia la Plaza de las Cañas, y la de la Ciudad la parte que caía a la Calle Real, donde estaba la Pescadería, por estimar el Cabildo que ése era el lugar más idóneo para hacer la oficina del peso que la Ciudad quería.

Por lo que respecta a las Carnicerías del Salvador, la Catedral ofreció dos posibilidades: una, que el Ayuntamiento edificara a su costa tres tiendas y que los beneficios se repartiesen a medias entre la Ciudad y la Iglesia, y la otra, que, dividido el solar en tres partes, tomara el Ayuntamiento una de ellas y las dos restantes fueran para la Catedral, pudiendo cada parte edificar en ellas lo que estimasen conveniente.

Al día siguiente de estas decisiones, el 7 de febrero de 1528, el Cabildo diputó al canónigo Martín Hernández y a otros para que, junto con el maestro mayor Hernán Ruiz, fuesen a valorar las obras de referencia ${ }^{30}$. En marzo del mismo año parece que se había llegado a un acuerdo con el Ayuntamiento, con la única salvedad de trasladar el Rastro de la Corredera no a la Puerta de Gallegos

28. YLLESCAS ORTIZ, María y otros: La Plaza de la Corredera. Córdoba, 1986, pág. 80.

29. Acuerdos entre la Ciudad y el Cabildo en relación con terrenos de la Corredera. A.C.C. Actas Capitulares 1525-1533, t.10, sin foliar.

30. 7 de febrero de 1528: Se faculta a los capitulares Martín Hernández, Alvar Alonso, Ojeda y Andrés García para que vayan con el maestro Hernán Ruiz al reparto del Rastro y San Salvador. A.C.C. Actas Capitulares 1525-1533, t. 10, sin foliar. 
sino a la Puerta del Sol, para lo cual el Cabildo otorgó los correspondientes poderes para pedir permiso al emperador ${ }^{31}$. Dos semanas más tarde, Hernán Ruiz es enviado en comisión con Pedro Ponce, Alonso Sánchez de Avila y otros a ver las casas destinadas a mercado en la Puerta del Sol ${ }^{32}$.

En junio de 1530 llegaría el permiso de la Corona para realizar el concierto y en febrero de 1544 la Ciudad derribó por fin las casas de la Corredera que eran propiedad del Cabildo, ocasión que aprovechó éste para enviar la correspondiente comisión que supervisara los derribos ${ }^{33}$.

El concierto entre la Ciudad y la Iglesia tendría un vigencia llena de dificultades y sometida a frecuentes pleitos que exasperarían sin duda a las autoridades, como parece demostrar el hecho de que el obispo fray Bernardo de Fresneda, en diciembre de 1573, llegara a ofrecerse como mediador entre canónigos y concejales para que de una vez resolviesen su diferencias urbanísticas ${ }^{34}$.

\section{Los pleitos del Rastro}

A partir de 1559 es el Ayuntamiento quien parece tomar la iniciativa y envía parlamentarios a la Catedral. En abril de ese año los veinticuatros don Diego de Córdoba y don Luis Páez de Castillejo, con el jurado Antonio de Córdoba, se presentan al Cabildo para exponerle que la Ciudad pensaba construir en las Carnicerías del Salvador con un proyecto valorado en 2.000 ducados y para ello solicitaban que el Cabildo cediese la casilla del contraste, con el fin de incluirla en la obra, y acrecentar así notablemente la renta que en dineros y gallinas pagaban por ella ${ }^{35}$. Los capitulares eclesiásticos contestaron con un desaire, reclamando de la ciudad que dejara libres las Carnicerías respetando los antiguos privilegios eclesiales que les permitían disponer libremente de ellas y establecer sin trabas la renta que correspondiese. El asunto había irritado visiblemente a los canónigos y beneficiados, quienes aprovecharon las circunstancias para remover antiguos motivos de litigios, como el precio en que se había tasado por la ciudad el Rastro de la Corredera o lo referente al impuesto de sisa y el uso de la aduana ${ }^{36}$.

Al cabo de casi cuarenta años de pacientes gestiones, el Ayuntamiento no encontró mejor salida que pasar decididamente a la acción, a sabiendas de que se

31. 19 de marzo de 1528: Poder del Cabildo a D. Francisco de Benavides y D. Diego de Aguayo para dirigirse al emperador. A.C.C. Actas Capitulares 1525-1533, t. 10, sin foliar.

32. A.C.C. Actas Capitulares 1525-1533, t. 10, sin foliar.

33. A.C.C. Actas Capitulares $1525-1533$, t. 10, sin foliar, Idem, 1541-1545, t. 12, sin foliar.

34. A.C.C. Actas Capitulares 1572-1577, t. 22, fol. 4 v. - 5.

35. 17 de abril de 1559: la Ciudad pide al Cabildo unas casas para mejorar la Corredera. A.C.C. Actas Capitulares 1558-1560. t, 16, sin foliar.

36. Ibidem. 
enfrentaba a un largo calvario de pleitos. En efecto, en 1567 valoró por su cuenta las casas de la Corredera y acto seguido mandó derribarlas ${ }^{37}$, lo que originó la consiguiente tensión entre ambos poderes, si bien ante la evidente necesidad del ensanche de la plaza, el Cabildo Catedral adoptó la actitud de sacar el mayor beneficio posible de la delicada situación. En mayo del 68 el Cabildo dio poder a un procurador para reclamar a la Ciudad 85.000 maravedíes de las casas del ensanche de la Corredera, pero en octubre del siguiente año nombró una comisión para que llegara a una concordia con la misma en la forma y condiciones que mejor le pareciere ${ }^{38}$.

El asunto tardó años en resolverse; en 1570 el Cabildo pagó 9.000 maravedíes a un tasador de la villa de Pedroche -el maestro Carrasquilla- encargado de fijar el precio por las casas, que sería insistentemente solicitado al Municipio ${ }^{39}$. Este a su vez, no estaba dispuesto a pagar más allá de ciento dos mil maravedíes, y así lo hizo saber a los canónigos en 1573, los cuales, como solían, nombraron una comisión para ver si podían obtener mayores beneficios ${ }^{40}$. Se sucedieron los pleitos a lo largo de ese año, pleitos que rindieron su fruto a favor de los canónigos, pues la ciudad fue condenada en 26.000 maravedíes; de esta cantidad se pagaron 250 reales al maestro de cantería Hernando de Zavala que se había encargado de tasar el Rastro Viejo de la Corredera en $1574^{41}$. En ese año la Ciudad pidió al Cabildo como otra salida posible que le vendiese el sitio del Rastro, pero no debió llegarse a acuerdo porque en noviembre de 1576 el corregidor rogó a la Iglesia que apreciase el valor del Rastro Viejo por lo necesario que era para el bien común de la Ciudad ${ }^{42}$. Sólo siete meses después encargaría el Cabildo al canónigo Fernando Gaitán que se ocupase de la tasación del citado lugar, con lo que pareció entrarse en el principio del fin ${ }^{43}$.

\section{El Rastro de la Ribera y la casilla de San Pedro}

En 1568 el segundo rastro, el que estaba situado entonces en la Ribera del Río, entre la Puerta del Sol y la calle de la Feria, se había trasladado al Campo de

37. Probablemente son éstas las casas del convento de la Encarnación cuyos bienes administraba el Cabildo Catedral que figuran como adquiridas por el Ayuntamiento para ensanche en 1567. Cfr. YLLESCAS ORTIZ, M. y otros: op. cit., pág. 4.

38. 7 de mayo de 1568: Poder a un procurador para cobrar del Municipio. A.C.C. Actas Capitulares 1565-1568, t. 19, fol. 145. 12 de octubre 1569: Comisión para tratar con la Ciudad en relación con el Rastro. A.C.C. Actas Capitulares 1568-1572, t. 20, fol. 70.

39. A.C.C. Actas Capitulares 1568-1572, t. 20, fol. 137.

40. A.C.C. Actas Capitulares $1572-1573$, t. 21, fol. 261 y v.

41. A.C.C. Actas Capitulares. 1572-1577, t. 22, fol. 17.

42. A.C.C. Actas Capitulares $1572-1573$, t. 21 , fol. $295-296$ y t. 22 , fol. 24 v. y 237 v.

43. A.C.C. Actas Capitulares 1572-1577, t. 22, fol. 296. 
la Verdad, con lo que los canónigos tuvieron un nuevo motivo de pleito con la ciudad en relación con los terrenos liberados con ese cambio ${ }^{44}$. Ya en 1572 el Cabildo se adelanta denunciando ante la Chancillería de Granada que el Ayuntamiento pretendía labrar en el sitio del Rastro Viejo de la Puerta del Sol, lo que revela el interés por defender y conservar los privilegios económicos sobre los rastros obtenidos desde tiempos del rey D. Juan II; para refrescar la legislación se encargó un estudio a los letrados acerca de las concesiones reales y de los posibles perjuicios que pudieran seguirse del concierto que había de hacerse con la Ciudad sobre el Rastro Viejo ${ }^{45}$.

En 1580 se hizo venir al arquitecto Martín Ruiz, al que se cita como "maestro de la obra de la iglesia de Luque", para que tasara el sitio del Rastro de la Puerta del Sol por parte del Cabildo, en tanto que la Ciudad hacía otra tasación como parte del proceso que se seguía ante el provisor por desacuerdo en la valoración del lugar ${ }^{46}$. El documento permite conocer el cargo de Martín Ruiz en la fábrica de la parroquia de Luque. Martín Ruiz es hijo de Hernán Ruiz II y hermano del maestro mayor de la Catedral Hernán Ruiz III. La iglesia se había comenzado a construir en 1567 por decreto del obispo don Cristóbal de Rojas, y con proyecto del maestro mayor Hernán Ruiz II. La presencia documentada de Hernán Ruiz III y Juan de Ochoa y la propia dirección de obra por Martín Ruiz suponen intervenciones distintas que explican suficientemente las variaciones y licencias que se aprecian en relación a lo que presumiblemente sería el proyecto original ${ }^{47}$. Quedó terminada en lo fundamental en 1598.

A partir de 1573 se une al pleito de los rastros el de la casilla de San Pedro ${ }^{48}$. En efecto, el Ayuntamiento solicitó en julio de ese año la cesión de una casa que la Catedral tenía en una esquina de la Plaza de San Pedro y que entorpecía la circulación, por lo que el Ayuntamiento pretendía su derribo para ensanche de la plaza. Probablemente se guardaba muy mal recuerdo del paso de la cabalgata regia por aquel estrecho lugar tres años antes; el interés por esta casa es tal, que incluso el corregidor intercedió en favor de la Ciudad por medio del arcediano de Castro, don Gonzalo Flores de Carvajal, asegurándole que la Ciudad la pagaría por encima de su valor, y expresando igualmente su preocupación por el pleito del Rastro Bajo de la calle Feria ${ }^{49}$.

44. RAMIREZ DE ARELlANO, Teodomiro: Paseos por Córdoba. Reedición, Córdoba, 1983, pág. 220.

45. A.C.C. Actas Capitulares 1578-1579, t. 23, sin foliar.

46. A.C.C. Actas Capitulares 1580-1582, t. 25, fol. 92.

47. ARJONA CASTRO, A., ESTRADA CARRILLO, V.: Historia de la villa de Luque. Córdoba, 1977, págs. 314 y ss.

48. A.C.C. Actas Capitulares $1572-1573$, t. 21 , fol. 202 y v.

49. A.C.C. Actas Capitulares $1572-1577$, t. 22 , fol. 76 v. 
Debió pasarse el verano en idas y venidas y pláticas sobre estos dos asuntos, hasta el punto de que el corregidor perdió la paciencia en relación con la casa, que hacía esquina con el cementerio de San Pedro. A fines de agosto el Ayuntamiento cortó por lo sano y procedió a derribar por su cuenta la parte de casa que estorbaba para el ensanche; como es natural el Cabildo recibió airadamente la noticia, culpando al corregidor por no haber asistido a las reuniones para tratar sobre la casa y entablando el pleito correspondiente. El 18 de septiembre el Ayuntamiento con actitud decididamente pragmática pide al Cabildo que acepte 50.000 maravedíes por lo derribado, pero los canónigos rechazarían la propuesta por considerar muy baja la valoración del inmueble.

Con ese mismo espíritu ejecutivo, el Ayuntamiento pidió un año más tarde a la Iglesia la venta del sitio del Rastro del Río, en tanto que se seguía el pleito por la casa de San Pedro ${ }^{50}$. Este último asunto quedará finalmente zanjado en marzo de 1582 al aceptar los canónigos los cincuenta mil maravedíes que ofrecía la ciudad en reparación por el derribo de la esquina de San Pedro, no sin que dicha aceptación llevara aparejada una última tentativa del Cabildo para que, si era posible, se les pagara más ${ }^{51}$.

Por lo que respecta al Rastro del Río, el Cabildo consiguió aburrir a la Ciudad; entre ambos poderes se llegó a un concierto para la adquisición por parte de aquella, pero la tasación que hicieron los veedores propuestos por la Catedral en 1580 fue tan alta, que el Ayuntamiento determinó “...que el Cabildo se tome su solar y haga de él lo que quisiere". Inmediatamente los canónigos dieron orden de que se cercara el sitio del Rastro Viejo de la Puerta del Sol a la vista de que la Ciudad desistía del pleito ${ }^{52}$.

Parecía que corrían nuevos aires de concordia cuando en 1583, en prueba de cortesía, el Cabildo delegó en dos capitulares para dar la bienvenida al nuevo corregidor, don Juan Gaitán de Ayala ${ }^{53}$.

\section{EL CONVENTO DE LA ENCARNACION}

En su testamento de 1503, el canónigo Antón Ruiz de Morales dispuso que se constituyera en sus casas de la calle del Duque una fundación para doce mujeres, gobernadas por su sobrina Juana González y gestionada por el deán y Cabildo de la Catedral cordobesa como patronos perpetuos. El Cabildo quedaba constituido

50. A.C.C. Actas Capitulares $1572-1573$, t. 21 , fol. $225-226$ y 244 y v.

51. A.C.C. Actas Capitulares 1572-1577, t. 22, fol. 24 v. Idem 1580-1582, t. 25 , fol. 168 y v.

52. A.C.C. Actas Capitulares $1579-1580$, t. 24 , fol. 129 y 132 v.

53. 10 de mayo de 1583: Se nombran dos capitulares para ir a dar la bienvenida al nuevo corregidor. Actas Capitulares 1582-1583, t. 26, fol. 125. 
como propietario y encargado de administrar cuanto tuviera relación con la casa. En 1509 la fundación se erigió en monasterio con la regla de San Benito ${ }^{54}$. La primitiva iglesia y el edificio en cuestión debían ser de fábrica relativamente pobre, lo que lleva a constantes reparaciones, que se hicieron más necesarias tras el incendio de $1559^{55}$. En 1566 se cambió la puerta del convento frente a la puerta de la iglesia, es decir a la calle Encarnación ${ }^{56}$, comenzando la serie de trabajos que van a transformar a lo largo de los años sucesivos la fachada de la calle del Duque, hoy de Rey Heredia. La comunidad debió tomar por entonces conciencia de su importancia avalada probablemente por las cuantiosas dotes y por las continuas peticiones de ingreso; síntoma evidente será el inicio de reformas y obras nuevas e incluso el cambio de título de la priora, que en 1576 deja de ser presidenta del convento para pasar a ser abadesa, porque así se llamaban las prioras en los monasterios de la orden de San Benito ${ }^{57}$.

En 1579 se solicita el ensanche del convento mediante la incorporación de un azucaque que daba a la calle del Duque en el que existía un postigo de una casa del Cabildo ocupada entonces por el canónigo tesorero. La operación consistía en la compra de la casa y en la incorporación de la calle, con la condición de darle salida a la casa del Cabildo ${ }^{58}$. En julio del siguiente año éste aceptó las condiciones pactadas para la incorporación de la calleja, regulando la situación de las casas en que vivía el tesorero D. Pedro Fernández de Valenzuela, quien dio el beneplácito para la obra, previo el visto bueno del maestro mayor Hernán Ruiz III.

La obra consistía esencialmente en la apertura de una puerta frente a la caballeriza de la casa del citado canónigo, con su portal y entrada en arco, más las hojas correspondientes de madera de pino y un pilar para recoger las aguas. Se ve afectado igualmente el patio, al que se ha de quitar el pavimento para disponer el alcantarillado que permitiese vaciar las aguas en el madre vieja que corría por la calle del Duque "...por un caño que se ha de hacer por la dicha calleja de la anchura que pueda andar por él un hombre y limpiarlo" ${ }^{59}$. El gasto de las obras correría a cargo de la comunidad.

54. ORTI BELMONTE, M.A.: Córdoba monumental, artística e histórica. Excma. Diputación Provincial. Córdoba, 1980, pág. 452-453.

55. 16 de febrero de 1559: El Cabildo faculta al deán don Juan de Córdoba junto con el canónigo Alonso Sánchez y el racionero Navarro para que visiten el convento de la Encarnación y "puedan hacer sobre el incendio todo lo que convenga conforme a justicia y todo lo demás que conciema al remedio de aquella casa". A.C.C. Actas Capitulares 1558-1560, t. 16, sin foliar.

56. A.C.C. Actas Capitulares 1565-1568, t. 19, fol. 94. Idem. 1568-1572, t. 20, fol. 66 v. -67.

57. A.C.C. Actas Capitulares $1572-1577$, t. 22 , fol. 182 v.

58. A.C.C. Actas Capitulares 1577-1579, t. 23, sin foliar.

59. A.C.C. Actas Capitulares 1580-1582, t. 25, fol 1 y v. 
Es el ochenta acaso el año más febril de la centuria en la historia del convento; año en que se emprenden obras importantes por parte de una comunidad que evidentemente no estaba dispuesta a someterse sin más a la voluntad del Cabildo. En febrero de ese año la abadesa y la comunidad solicitan autorización para "reedificar su iglesia, atento que el edificio de ella es antiguo y está mal parado". En respuesta se nombraron los usuales diputados con el cometido de averiguar si las monjas disponían del suficiente capital para emprender la obra ${ }^{60}$. Pero las religiosas, que no estaban para dilaciones, no esperaron al permiso del Cabildo; realmente da la impresión de que cuando solicitaron la venia ya se habían iniciado los trabajos, a juzgar por los detalles que se registran en acta con motivo de la airada protesta de los capitulares, los cuales amenazaron "so pena de suspensión a la abadesa y a las demás oficiales del dicho monasterio y que se procederá contra ellas como inobedientes a su prelado..." ${ }^{61}$. Esta requisitoria se produjo cuando no hacía ni un mes de la petición de licencia y para entonces ya estaba iniciada la obra de la iglesia y casi terminados los tres arcos del compás de la misma. El Cabildo, en consecuencia, permitió que se acabase la arquería comenzada pero prohibió que se siguiese la obra del templo.

De todos modos las monjas habían dado un paso difícil de frenar; al tiempo que el Cabildo las conminaba, suplicaron licencia para acabar y asentar la portada de piedra que había de ser de la iglesia y que estaba ya casi terminada. Obtuvieron el permiso con la reiteración de que "no innovasen más obra ni edificio alguno sin licencia expresa del Cabildo" ${ }^{62}$. Entre los escasos restos visibles que este cenobio tiene del XVI se conserva afortunadamente esta portada de cantería, cuyo estilo refleja la mano creadora de Hernán Ruiz III. El dibujo es muy sencillo: dos jambas cajeadas y recompuestas en la zona inferior soportan un arco semicircular al que da cobijo una cornisa tangente de dentellones. La disposición de esta cornisa, ciertamente anticlásica, trae a la memoria el recuerdo de la tradición mudéjar del alfiz, tan usado por esta familia a lo largo de la centuria: Sin embargo es mucho más fuerte el espíritu renacentista y la asimilación de los modelos de Serlio, patente en la decoración de la rosca del arco, inspirada igualmente en soluciones planteadas por su padre en el Manuscrito de Arquitectura, en especial la rosca del folio $43^{63}$.

Por estas fechas y bajo la dirección de Hernán Ruiz III, debió labrarse también la portada principal de la casa, que abre a la calle de la Encarnación. Fue

60. A.C.C. Actas Capitulares $1579-1580$, t. 24 , fol. 87 v.

61. A.C.C. Actas Capitulares 1579-1580, t. 24, fol. 98 y v.

62. A.C.C. Actas Capitulares 1579-1580, t.. 24, fol. 99 v.

63. Cfr. NAVASCUES PALACIO, Pedro: El libro de Arquitectura de Hernán Ruiz, el Joven. Madrid, 1974, lám. XLII 
profundamente reformada en $\mathbf{1 7 5 8}$ pero se conservó el remate de la obra primitiva, una capilla con un bello relieve pétreo de la Encarnación, surmontado por el medio punto con el Padre Eterno. Marco y escultura se integran admirablemente en la composición, limitada lateralmente por sobrias pilastras que se prolongan con dos urnas muy características de la estética de los Hernán Ruiz. Un guardapolvo sirve de culminación al conjunto, decorándose con una suerte de frontón mixtilíneo con óvalo en el tímpano y esferas como acróteras, solución inspirada sin duda en la que presenta el folio 110 del Manuscrito de Arquitectura ${ }^{64}$.

De poco sirvieron las cautelas capitulares ante comunidad tan emprendedora, pues antes de un mes las monjas ya habían convencido a los hermanos Martín y Pedro de Medina para que fabricaran a su costa la capilla mayor de la iglesia a cambio de disponer en ella su enterramiento familiar ${ }^{65}$. Ante decisión tan irrefutable, los capitulares nombraron una comisión presidida por el maestrescuela Francisco Morillo para que convenciera a la comunidad de que se labraran las zonas del monasterio más necesitadas de arreglo y detuvieran en lo posible las obras de la iglesia hasta analizar los títulos y escrituras que tenían los hermanos Medina y si aquellas eran suficientes para garantizar la obra completa de la capilla mayor ${ }^{66}$. A la vista de los informes de la Comisión, se admitió la necesidad de edificar la iglesia nueva y se autorizó a levantar un lienzo de muro que constituiría una de las paredes de la iglesia, la que lindaba con el convento. Se aducen para ello razones de utilidad, ya que al construirse la pared se emplearían los materiales acumulados en el convento, que estorbaban el normal funcionamiento de la casa. Se acepta igualmente que los Medina financien la capilla mayor ateniéndose a las condiciones que fije la comisión, autorizándoles a poner sus armas en aquella capilla pero no en las demás.

Existía un pasadizo en otra de las casas del Cabildo que estaba en la calleja de la Cárcel, luego de las Comedias, que comunicaba con la calle del Duque; en junio del 80 las monjas solicitan también que se incluya en el convento ${ }^{67}$, y unos días después piden que se cierre el postigo que se había abierto en el otro callejón de marras y que permitía el acceso a la casa de Pedro Fernández de Valenzuela ${ }^{68}$.

Siguiendo con la fiebre renovadora de 1580 , en octubre se pide permiso para elevar la pared del convento que lindaba con la casa del canónigo Juan Mohedano, el cual se ofreció a correr con los gastos. A pesar de ello, el Cabildo estimó

64. Idem, lám. XCVI.

65. A.C.C. Actas Capitulares $1579-80$, t. 24, fol. 111.

66. A.C.C. Actas Capitulares 1579-1580, t. 24, fol. 113.

67. A.C.C. Actas Capitulares 1579-1580, t. 24 fol. 140.

68. A.C.C. Actas Capitulares 1579-1580, t. 24, fol. 137. 
que con esa obra la casa de Mohedano se mejoraba sensiblemente, por lo que se le pidió que ofreciera alguna ventaja más ${ }^{69}$. El canónigo no debió admitir de buen grado las exigencias de su Colegio y dos años más tarde éste le conmina a que construya aquel muro colindante, indicándole con precisión cómo debe hacerlo, desde el cimiento hasta la altura y el grueso de la pared y desde luego el trazado de la misma y la obligación de que las aguas caigan a su propia casa y no al convento ${ }^{70}$.

La obra de la iglesia siguió a ritmo continuado y a comienzos de 1583 los patronos permitieron a la comunidad tomar un censo de 700 ducados, garantizado por las dotes de las novicias, con el fin de que se acabase la obra de la iglesia y coro "...por estar ya muy al cabo y tener las maderas y materiales en dicho convento" 71 . La última noticia importante que atañe a este momento constructivo del cenobio cisterciense revela igualmente el empuje de estas monjas y la resistencia a perder los estímulos más peculiares de su condición femenina. En efecto, la obra de la iglesia se culminó con un hermoso mirador situado encima de la puerta, el cual, según los patronos "...viene a ser tan esento e indecente que señorea y mira a toda la calle principal". El Cabildo ordenó su demolición sin que quedara señal alguna del mismo, encargando de tan enojoso cometido al arcediano de Pedroche, don Francisco de Montenegro y al racionero Diego Alonso de Lamariano, a la sazón administradores del monasterio ${ }^{72}$.

Las actas capitulares, que frecuentemente vuelven sobre el tema revelan la dificultad de resolver los dos asuntos más espinosos de la casa cisterciense: el muro que debía hacer el canónigo Mohedano, por ser muy baja la pared medianera con el convento ${ }^{73}$ y el precioso mirador que defendieron las monjas con recia voluntad en contra de sus patronos, tan poco sensibles a la necesidad que las santas mujeres tenían de otear, a hurtadillas al menos, los sucesos de la calle del Duque ${ }^{74}$.

69. A.C.C. Actas Capitulares $1580-1582$, t. 25 , fol, 36 .

70. A.C.C. Actas Capitulares $1580-1582$, t. 25 , fol. 168 .

71. A.C.C. Actas Capitulares 1582-1583, t. 26, fol, 17.

72. A.C.C. Actas Capitulares $1582-1583$, t. 26 , fol. 85 y v.

73. A.C.C. Actas Capitulares $1582-1583$, t. 26 , fol. 98 v.

74. A.C.C. Actas Capitulares 1583-1586, t. 27, fol. 23 v. 


\section{APENDICE DOCUMENTAL}

\section{DOCUMENTO N. 1}

Viernes 7 de febrero de 1528: El Cabildo designa representantes para tratar asuntos varios con la Ciudad.

A.C.C. Actas Capitulares 1525-1533, t. 10, sin foliar.

Diputados para repartir el sitio del Rastro y San Salvador (al margen)

"Este día diputaron para ir a ver cómo se ha de repartir con la ciudad lo del Rastro de la Corredera y Carnicería de San Salvador a los señores que antes estaban diputados y al canónigo Martín Hernández y Alvar Alonso y Hojeda y Andrés García que tienen consigo a Hernán Ruiz maestro mayor de esta iglesia".

\section{DOCUMENTO N. 2}

Jueves 2 de Abril de 1528: Nombramiento de representantes del Cabildo para el traslado del Rastro.

A.C.C. Actas Capitulares 1525-1533, t. 10, sin foliar.

"Este día diputaron sus mercedes para ir a ver a la Puerta del Sol lo que el señor mariscal pidió al Cabildo para ensanchar el Rastro, a los señores don Pedro Ponce y al licenciado del Pozo y Jarana y Hernán Ruiz con Alonso Sánchez de Avila y Andrés García que estaban de antes diputados para esto mismo, para que lo vean y hagan relación al Cabildo".

\section{DOCUMENTO N. 3}

Lunes, 20 de febrero de 1570: Normas del Cabildo para el recibimiento del rey Felipe II.

A.C.C. Actas Capitulares 1568-1572, t. 20, fol. 104-105.

"Señalar la hora.

Hánse de juntar todos los señores beneficiados en casa del Prelado y si el no fuęre allá, en las casas del señor que presidiere al son del aguijón (sic).

Han de ir todo el Cabildo cabalgando con lobas y becas en orden por sus antigüedades, de dos en dos, guiados por el pertiguero que ha de ir cabalgando con su ropa de seda y cetro de plata.

Llegados a vista de su Majestad, los delanteros pararán haciendo procesión para que los mayores pasen delante de manera que queden en orden por coros, los mayores delante, y apear se han por su orden para llegar a besar las manos de su Majestad por su antigüedad o hasta que su Majestad haga señal de que no vayan más. 
Uno de estos señores ha de estar a pie cerca de su Majestad para decirle los nombres de los beneficiados que llegaren a le besar las manos.

Después de haber besado las manos a su Majestad, se volverá el Cabildo por su orden como fueron a la iglesia y allí tomarán sobrepellices y capas de brocado y seda en el coro.

Háse de hacer en la Puerta del Perdón debajo de la imagen, un altar aderezado ricamente y en él una reliquia que es el vaso de vidrio.

Ha de ir el preste vestido con diácono y subdiácono, y el diácono ha de llevar el misal por donde se ha de decir la oración.

El sochantre ha de llevar capa de seda y la vara del compás.

Salidos del coro, irán en procesion a la Puerta del Perdón en silencio y el preste se firmará (sic) a la puerta y de allí adelante seguirá la procesión al contrario, yendo los menos antiguos hasta el Arco de las Bendiciones.

Saldrán fuera en apeándose el rey junto con (sic) la Puerta del Perdón el Obispo con sus asistentes y estará hecho estrado de frente del altar sobredicho para que se ponga de rodillas el rey, y allí el obispo o el preste echará el agua bendita si allí no estuviere cardenal, el cual la echará o el legado si lo hubiere; dada el agua bendita, volverá el preste o el obispo si fuere vestido de preste, y tomará la reliquia y los asistentes o dos dignidades más antiguos si fuere otro que el obispo vestido, después le ayudarán los brazos para que llegue al Rey a que bese la reliquia.

En habiéndose hecho esto luego comenzará el sochantre el responso Eleius debus (sic).

Volverán en procesión cantando el dicho responso hasta el altar mayor donde estará hecho otro estrado para su Majestad y otro para el Cardenal en un banquillo cubierto y una almohada en lo bajo a la parte de la epístola y el obispo se subirá al lado del altar mayor donde suele, y allí dirá los versos y oración Ut ynpontificali f. clxxv (sic), y dicha la oración el obispo en medio del altar echará la bendición solemne.

Si su Majestad llevare estandarte, irá delante del diácono y si llevare estoque el que lo lleva irá a la mano derecha del preste.

Han de poner todas las más capas de brocado que se pudiere.

Hánse de poner dos doseles de brocado para los dos estrados del rey y cuatro cojines y cuatro almohadas de brocado.

Han de venir todas las cruces y clerecía.

Yten se mandó a todos los señores beneficiados del Cabildo cumplan lo mandado so pena de los oficios de un mes". 


\section{DOCUMENTO N. 4}

Jueves 17 de Marzo de 1580: El Cabildo ordena a la comunidad de la Encarnación que paralice las obras porque no tiene licencia para ello.

A.C.C. Actas Capitulares $1579-1580$, t. 24, fol. 98 y v.

"Este día habiendo entendido el Cabildo que la Abadesa y monjas de la Encarnación hacían ciertos edificios y labraban piedra para edificar una iglesia en el dicho monasterio y que no tenían para ello licencia del Cabildo ni de los señores visitadores y que excedían de lo ordenado por el estatuto que de esto trata, el Cabildo determinó que no hiciesen la iglesia que pretendían y que solamente se acabasen los tres arcos que tienen comenzados y que no innoven otra obra sin expresa licencia del cabildo, so pena de suspensión a la abadesa y las demás oficiales del dicho monasterio y que se procederá contra ellas como inobedientes a su prelado y mandaron a mí el secretario de estos autos se lo notifique...".

\section{DOCUMENTO N. 5}

Martes 22 de marzo de 1580: Autorización para hacer una portada.

A.C.C. Actas Capitulares $1579-80$, t. 24 , fol. 99 v.

Que se haga una portada en el monasterio de la Encarnación (al margen)

"Este día, habiéndose leído una petición de la abadesa y monjas de la Encarnación en que pedían y suplicaban al Cabildo les diese licencia para acabar y asentar una portada de piedra que tienen comenzada para la puerta que ha de ser de la iglesia que pretenden hacer, el Cabildo, viendo la necesidad que de ella había y que estaba ya muy al cabo para la acabar, dio licencia que la acabasen, la asentasen y que no innovasen más obra ni edificio alguno sin licencia expresa del Cabildo".

\section{DOCUMENTO N. ${ }^{\circ}$}

Sábado, 30 de Abril de 1580: Autorización del Cabildo para levantar una de las paredes de la iglesia.

A.C.C. Actas Capitulares 1579-1580, t. 24, fol. 114 v.

"Este día los señores maestrescuela y administradores canónigo doctor Velasco y racionero Yllescas del monasterio de la Anunciación, hicieron relación al Cabildo como diputados de la necesidad que había de labrar y edificar la iglesia en dicho convento y para desembarazar la casa de tierra y piedra y materiales era muy bien acertado se haga un lienzo de la una pared que ha de ser de la dicha iglesia de largo a largo hacia la parte del dicho convento y que Martín y Pedro de Medina pues tienen su entierro en el altar mayor, hagan la capilla mayor de la dicha iglesia con las condiciones y orden que dieren los dichos señores maestrescuela y administradores y que puedan ponerse las armas de los dichos... en la dicha capilla y no otras". 


\section{DOCUMENTO N.ㄱ7}

Lunes 21 de julio de 1580: Relación de las obras que desean hacer las monjas de la Encarnación.

A.C.C. Actas Capitulares $1580-1582$, t. 25 , fol. 1 y v.

"Este día ... el Cabildo ... habiendo oido la relación del doctor don Francisco de Morillo, maestrescuela y lo de los demás señores diputados sobre la calleja sin salida que el convento y monjas del monasterio de la Encarnación pretenden meter dentro de su casa, donde tiene un postigo la casa de estatuto donde al presente vive el señor canónigo Pedro Fernández de Valenzuela, y entendido por la dicha relación que la dicha casa no recibe daño de que se cierre el dicho postigo, obligándose las monjas como se quieren obligar a hacer cierta obra por el patio de fuera y por la caballeriza de la dicha casa que sea tránsito al servicio de las mujeres por donde puedan entrar todas las cosas que entraban por el dicho postigo, según y en la manera que Hemán Ruiz maestro mayor de la obra de esta Iglesia dijo que convenía que se hiciese para sanear todo el daño de cerrarse el dicho postigo, y atento así mismo que el dicho señor canónigo Pedro Fernández de Valenzuela que tiene de por vida las dichas casas consiente en ello, y que las dichas monjas han comprado unas casas arriba de la dicha calleja para meter dentro del dicho convento y no pueden cómodamente hacerlo si no meten también la dicha calleja para lo cual tienen licencia de la ciudad, por las dichas causas y razones y por la necesidad que el monasterio tiene para la iglesia que al presente hace y otras obras que se han de hacer de aprovecharse la dicha calleja, el Cabildo hizo gracia al dicho convento de que el postigo de la dicha casa de estatuto se cierre en manera que no se pueda usar de él y la calleja se pueda meter dentro del dicho convento, habiendo sido votado por pelotas como se votan las cosas de gracia, lo cual el Cabildo le dio y concedió con que ante todas cosas se hagan y cumplan las cosas siguientes:

Primeramente se ha de abrir una puerta enfrente de la de la caballeriza de la dicha casa de estatuto donde vive el dicho señor canónigo Pedro Fernández de Valenzuela del tamaño de la que al presente tiene la dicha caballeriza y poner puertas en ella y así mismo se ha de hacer un arco del tamaño de la dicha puerta que salga al servicio de las mujeres con un portal delante y con su plancha de pino y un pilar de ladrillo para que las aguas no entren a caballeriza donde también se han de poner puertas.

Yten se ha de desempedrar el patio y bajarlo lo que convenga y volverlo a empedrar aviando (sic) la corriente de las aguas a un cauchil que se ha de hacer donde sea necesario para que las aguas desde este cauchil vayan a la madre vieja que va por la calle del Duque por un caño que se ha de hacer por la dicha calleja de la anchura que pueda andar por él un hombre y limpiarlo.

Todo lo cual se ha de hacer a costa del dicho convento y a contento del dicho Hernán Ruiz maestro mayor antes que se cierre el postigo de la dicha casa de estatuto, ni las monjas metan dentro del convento la calleja.

Y con las condiciones arriba dichas el Cabildo hizo la dicha gracia y no cumpliéndose todas o algunas de ellas, desde luego el Cabildo dijo que la revocaba y daba por ninguna". 


\section{DOCUMENTO N. .8}

Sábado 24 de marzo de 1582: Condiciones que debe cumplir el canónigo Mohedano para levantar la pared lindera con el convento.

A.C.C. Actas Capitulares 1580-1582, t. 25, fol. 168.

“...Se ha de sacar de zanja apañino (sic) con la pared del portal de la casa del dicho Antonio Mohedano y tirarse derecha a la larga hasta la pared frontera del dicho monasterio de suerte que entre dentro del corral del dicho monasterio todo el grueso de la pared y esto lo gane estotra casa... el dicho... ha de hacer toda la pared a su costa ... y la ha de hacer hasta emparejar con el tejado del corredor de la dicha su casa y ha de hacer las aguas a su casa y no a la parte del dicho monasterio".

\section{DOCUMENTO N.ㅇ 9}

Martes 11 de enero de 1583: Autorización al monasterio de la Encarnación para un censo de 700 ducados.

A.C.C. Actas Capitulares 1582-1583, t. 26, fol. 77.

“...que el convento acabe la obra comenzada de la iglesia y coro por estar ya muy al cabo y tener las maderas y materiales en el dicho convento..."

\section{DOCUMENTO N.10}

Sábado 22 de enero de 1583: El Cabildo ordena derribar el mirador del convento de la Encarnación.

A.C.C. Actas Capitulares $1582-1583$, t. 26 , fol. 85 y v.

"Este día habiendo platicado el cabildo sobre las razones y causas que hay para mandar deshacer el mirador que las monjas de la Encarnación habían hecho encima de la obra nueva, por cuanto el dicho mirador estando como está sobre la puerta grande de la iglesia del dicho monasterio viene a ser tan exento e indecente que señorea y mira a toda la calle principal, y de consentirlo así se podría seguir muchos inconvenientes, el Cabildo procurándolos obviar determinó y mandó que el dicho mirador se demuela y quite todo sin que de él quede señal alguna y se cometió a los señores don Francisco de Montenegro arcediano de Pedroche y Diego Alonso Lamariano racionero, administradores del dicho monasterio que así lo ejecuten y hagan cumplir..." 


\section{DOCUMENTO N. 11}

Martes 8 de marzo de 1583: Ordenes del Cabildo relativas a las obras de la Encarnación. A.C.C. Actas Capitulares 1582-1583, t. 26, fol. 98 v.

“... que remedien y reparen el mirador que se ha hecho en el convento de la Encarnación y cierta pared que está baja la parte de la casa en que vive Alonso Mohedano y todo lo demás que les pareciere que conviene a la custodia y buen gobierno del dicho monasterio".

\section{DOCUMENTO N. 12}

Viernes 7 de noviembre de 1583: Se autoriza a los administradores del monasterio de la Encarnación para que derriben el mirador.

A.C.C. Actas Capitulares 1583-1586, t. 27, fol. 23 v.

“... que quiten o cierren el mirador que tienen las monjas de la Encarnación o derribándolo de todo punto o cerrándolo de tal manera que no puedan de allí tener vista a ninguna calle de la ciudad poniendo sin ninguna dilación por obra lo que muchas veces ha sido por este Cabildo ordenado y haciendo en todo lo que más a los dichos señores les pareciere convenir". 

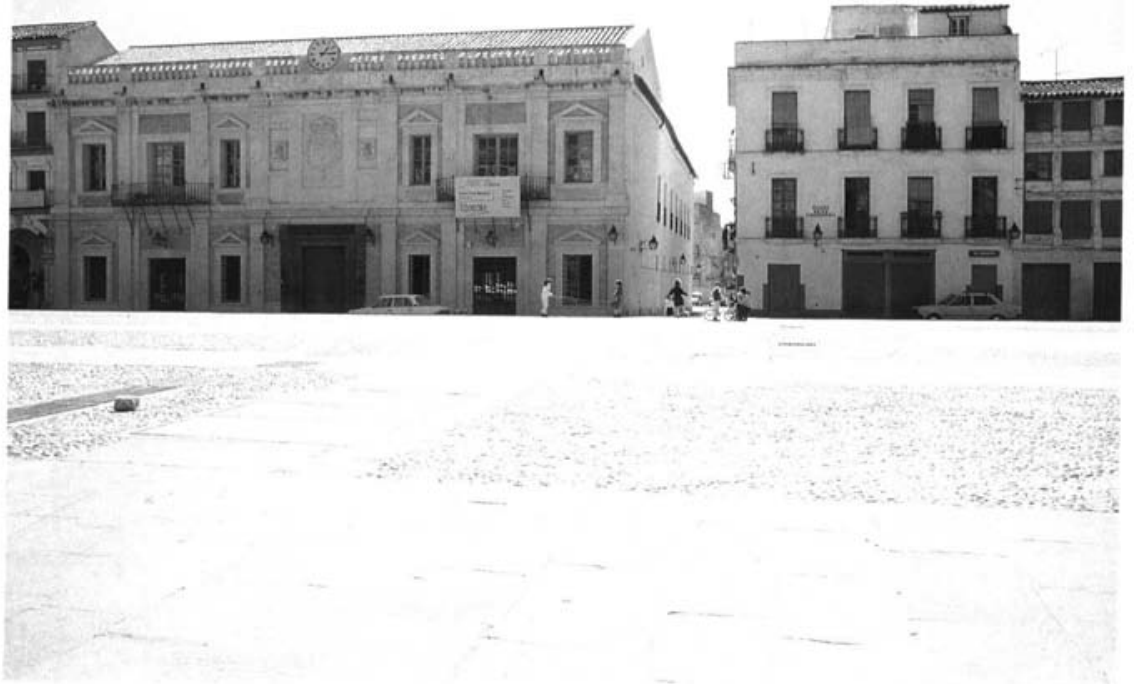

1. Lugar del Rastro de la Corredera ocupado por las casas de la Catedral que fueron derribadas por la Ciudad en 1544. En el solar se construyó posteriormente la Cárcel y Casa del Corregidor por Juan de Ochoa (1586). 


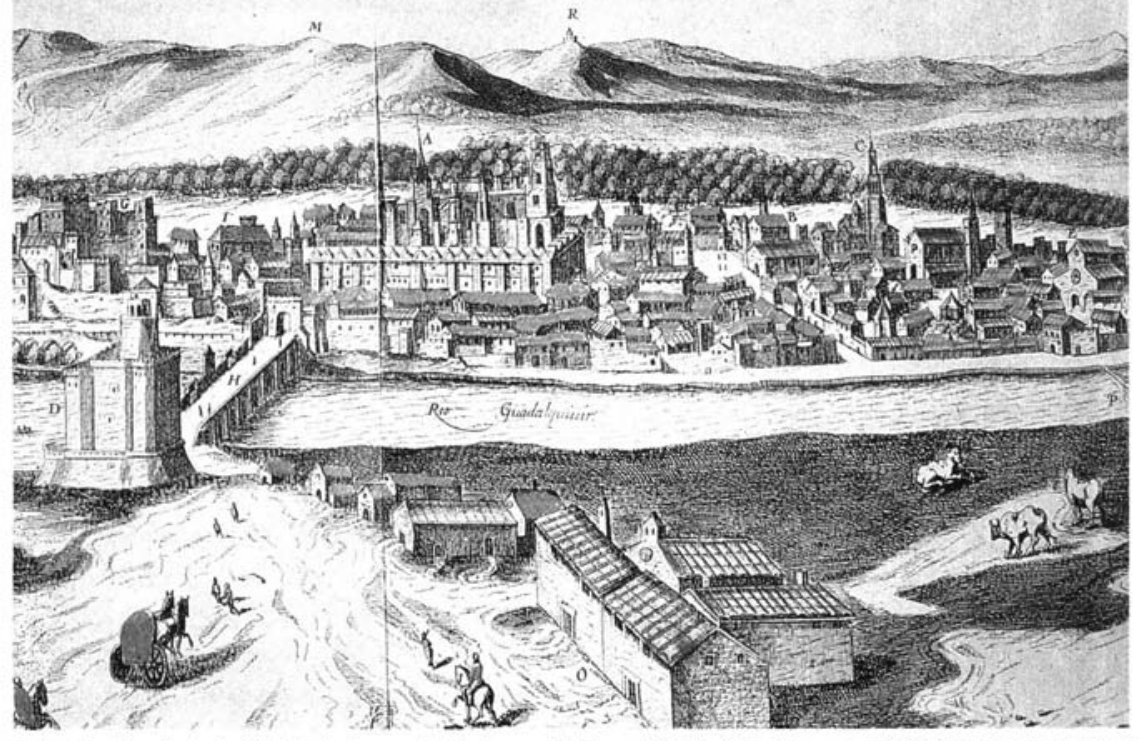

2. Detalle del grabado de Córdoba hecho por Hoefnagle para G. Braun, Civitatis Orbis Terrarum (1572-1612). Se representan en él los terrenos del Rastro Viejo de la Ribera, entre la Puerta del Sol y la calle de la Feria, y el Rastro Nuevo junto a la Calahorra, en el Campo de la Verdad. 


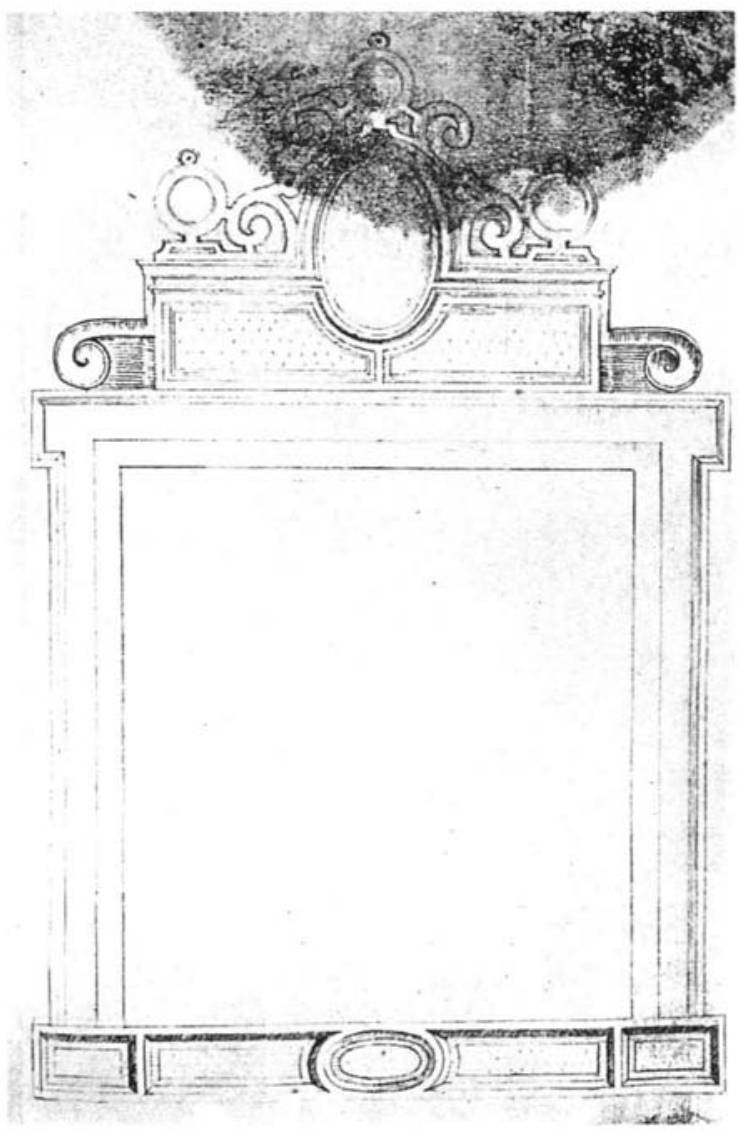

3. Hernán Ruiz el Joven: Folio 110 del Manuscrito de Arquitectura. Edición de Pedro Navascués, lám. XCVI. 


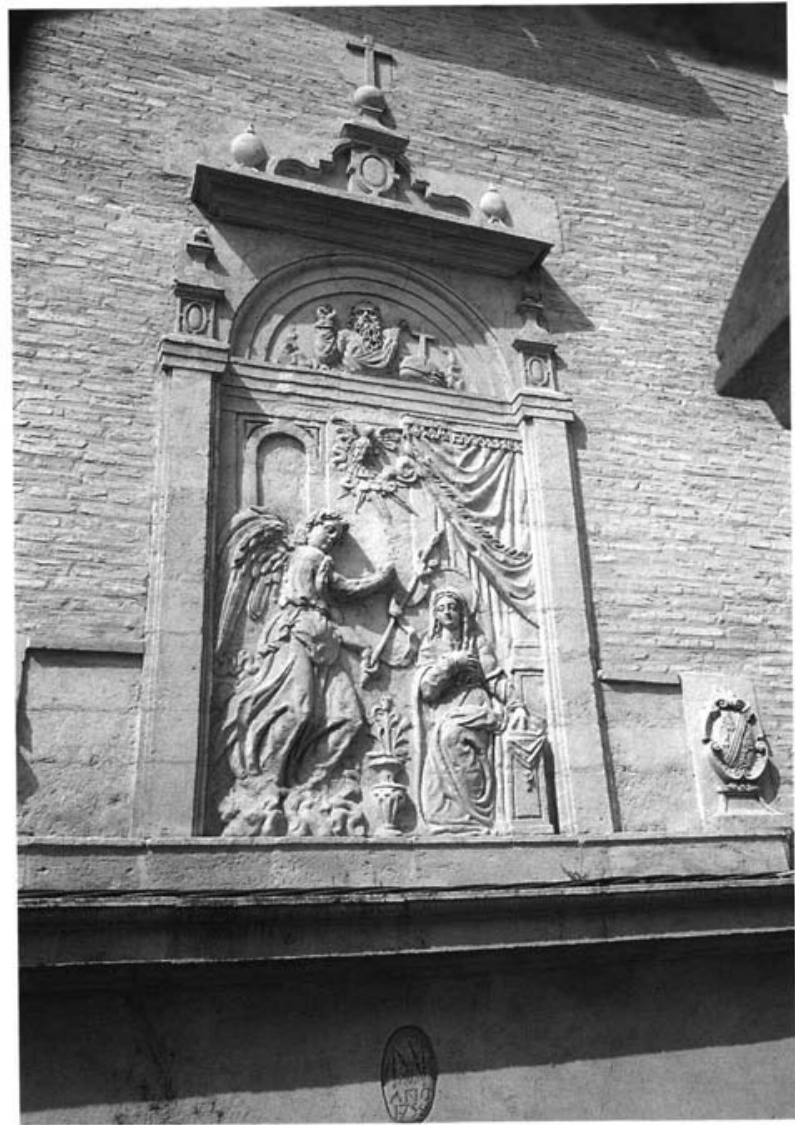

4. Hernán Ruiz III. Remate de la portada del convento de la Encarnación. 1580-1584. 


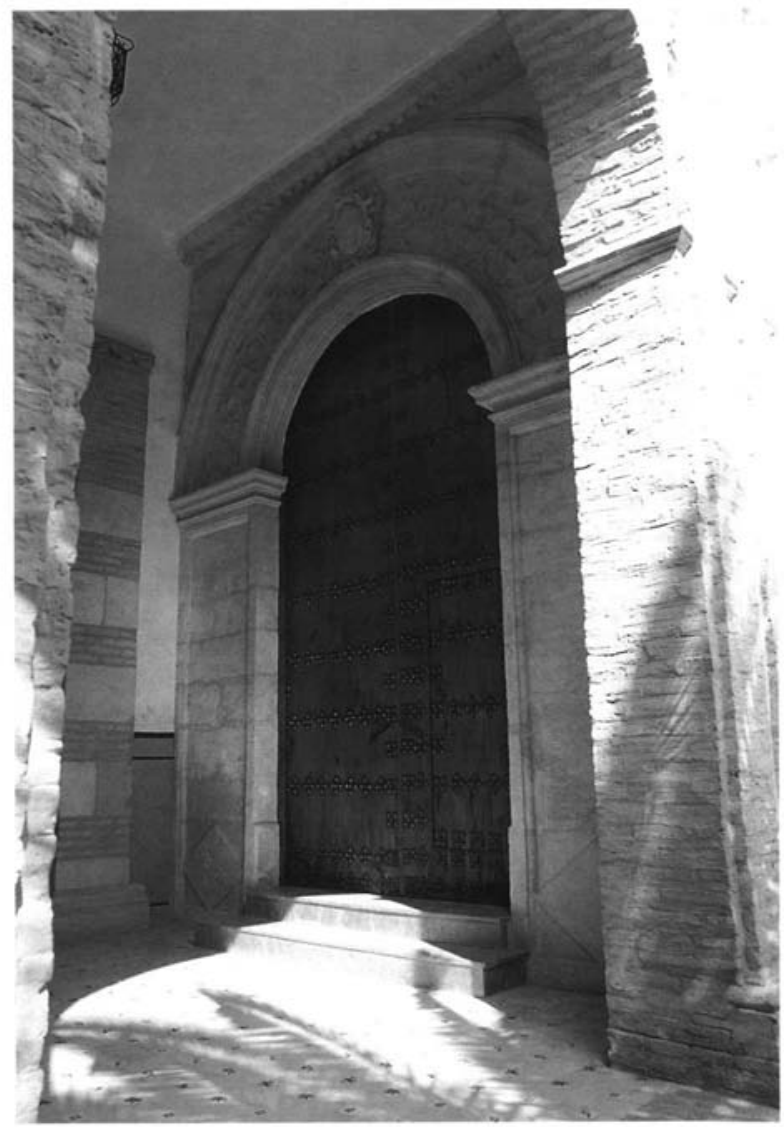

5. Hernán Ruiz III. Portada de la iglesia conventual de la Encarnación. 1580-1584. 


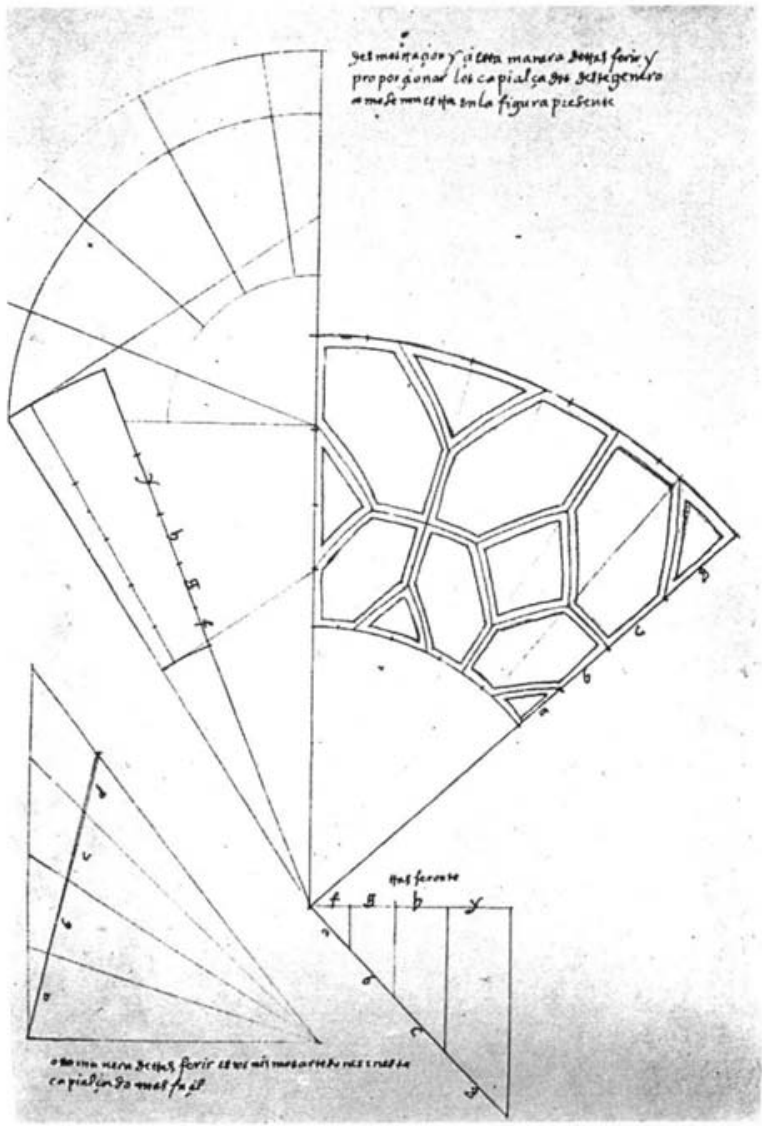

6. Hernán Ruiz el Joven: Folio 43 del Manuscrito de Arquitectura. Edición de Pedro Navascués, lám. XLII. 


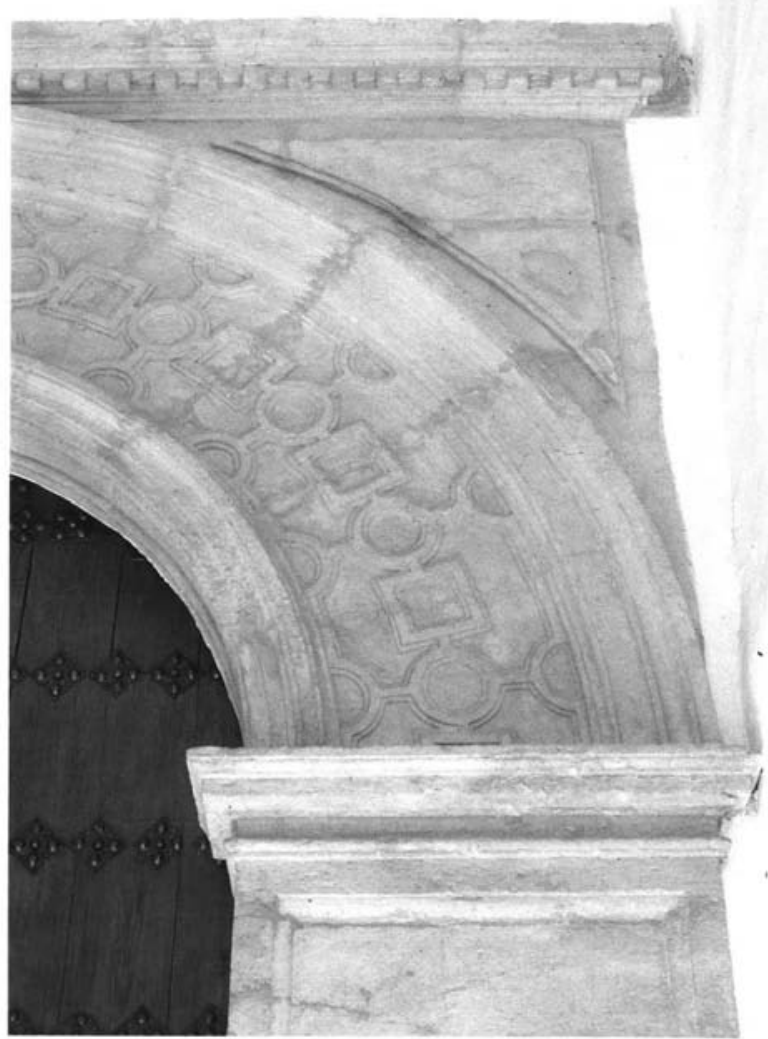

7. Hernán Ruiz III. Detalle de la rosca del arco en la portada de la iglesia de la Encarnación. 